Millatī, Journal of Islamic Studies and Humanities

Vol. 4, No. 1, Juni 2019: p. 35-52. DOI: 10.18326/mlt.v4i1. 35-52

p-ISSN : 2541-3627; e-ISSN 2540-9964

Website: http://millati.iainsalatiga.ac.id/index.php/millati/index

\title{
A Comprehension Transfer of Wahabiyah in Recitation System
}

\author{
Ernita Dewi \\ Faculty of Social and Political Sciences, UIN Ar-Raniry, Indonesia \\ fisip.prodiian@ar-raniry.ac.id \\ Eka Januar \\ Faculty of Social and Political Sciences, UIN Ar-Raniry, Indonesia \\ fisip.prodiian@ar-raniry.ac.id
}

\begin{abstract}
Wahabiyah which is claimed as a heretical ideology since it is not in line with Ahlul Sunnah Wal Jamaah stated by Tengku (ustad) in Pesantren become the research area in this study. This ideology is presumably from some acts of worship suh as not reading Qunut during Shubuh prayer and doing eigtht-rak'ah tarawih prayer. Furthermore, Wahabi is also pinned on to someone who does not participate in celebrating Prophet Muhammad birthday (Maulid Nabi). This tradition is celebrated in 4 months consecutively in the form of kenduri (thanksgiving by bringing rice and some dishes to the mosque). Someone is appointed when she/he meets the requirements in which explained by the teacher in Pengajian. The problem lies when santri spontaneously labels everyone who does not follow rules of Ahlul Sunnah Wal Jamaah as Wahabi, including Muhammadiyah.
\end{abstract}

Keywords: Wahabiyah, Tengku Dayah, Muhammadiyah

\begin{abstract}
Abstrak
Faham Wahabiyah diklaim sebagai aliran yang sesat karena tidak sejalan dengan aqidah Ahlul Sunnah Wal Jamaah, statemen itu sering dilontarkan oleh para tengku (ustad) dalam pengajiian-pengajian di pesantren yang menjadi wilayah penelitian. Indikasi faham tersebut disinyalir dari praktek ibadah yang dilakukan seseorang, salah satunya adalah tidak membaca qunut ketika salat subuh,salat tarawih delapan rakaat. Klaim wahabi juga disematkan pada seseorang yang tidak ikut serta dalam merayakan peringatan hari kelahiran Nabi Muhammad. Tradisi Maulid Nabi Saw. Dirayakan sampai 4 bulan berturut-turut dalam masyarakat Aceh, dalam bentuk kenduri (syukuran di rumah disertai dengan membawa nasi dan lauk ke Mesjid. Penunjukan seseorang itu wahabi jika memenuhi unsurunsur seperti ini, dan ciri-ciri diperoleh seseorang setelah mendapatkan penjelasan dari gurunya di tempat pengajian. Problem mendasar dari masalah ini adalah, para santri yang telah mendapatkan informasi tentang karakteristik tentang faham Wahabi dari gurunya, maka secara spontan akan memberikan label wahabi untuk semua orang yang tidak melakukan hal-hal yang dipahami sebagai bentuk ajaran Ahlul Sunnah Wal Jamaah, termasuk untuk masyarakat yang tergabung dalam Muhammadiyah.
\end{abstract}

Kata Kunci : Wahabiyah, Tengku Dayah, Mubammadiyah 


\section{INTRODUCTION}

The negative stigma is often labelled in Muslim communities who are different in carrying out Islamic worship. For example, when they do not read Qunud, do not perform eating rituals on certain days, and do not celebrate Maulid in the form of parties by inviting relatives, they are labelled as Wahabi or heretical who will not survive in the world and hereafter. However, people appoint them as Wahabi not based on clear understanding and criteria. As long as they do not carry out the ordinary worship done by people, they are accused of being a Wahabi. ${ }^{1}$

This phenomenon is often found in traditional-basis pesantren. This thought arises because of ideology spread by the teacher. Taught in traditional Islamic school and called as Teungku, they are highly obeyed and followed by their students. All advices and knowledges are accepted. Likewise, when Tengku calls people do not practice worship as Ahlul Sunnah Wal Jamaah (ASWAJA) do, they are considered as Wahabi which is heretical.

In Aceh where Dayah become their basic in learning religion, Tengku Dayah is entrusted to teach them all about Islam. Teaching instilled by teungku is a truth that cannot be contested. Some santri know the truth based on one perspective only which as conveyed by Ttengku Dayah. Everything that is different from what they believe is considered wrong. This leads to anti-clerical attitude. In a psycho-emotionally immature society, differences are regarded as hostility though power that forms great civilizations is driven by differences itself. Furthermore, disagreement will lead to a more powerful and comprehension when it is discussed maturely. People must not feel that they are always on the right side. ${ }^{2}$ It is important to consider how truth is claimed by Islamic thoughts

In Indonesia, as stated by Nurcholis Madjid, Muslims' perceptions towards their religion are classified into two groups including traditionalist and modernist. Abou El Fadl, as quoted by Ahmad Syafi'i Maarif, called it puritanical Islam and modern Islam. Both are often involved in disputes as they consider as the truest and call the opponent as the Infidel. Moreover, in Aceh, traditionalist groups who study in traditional borading school is better known as Dayah.

\section{DISCUSSION}

\section{Comprehension Transfer System in Dayah Tradisional}

Teungku has a big role in transferring knowledge and influencing students' mindset. Great obedience of a Santri results a weak analysis when facing a problem apart from seeing others are wrong. As a teacher, Teungku gives enlightment related to all problems of life. Indoctrination should coincide with a wise and tolerant attitude in addressing various

\footnotetext{
${ }^{1}$ This data is based on the researcher experience and observation

${ }^{2}$ Maarif, Ahmad Syafi'i., Islam dalam Bingkai Keindonesiaan dan Kemanusiaan: Sebuah Refleksi Sejarah, (Bandung: Mizan, 2009), p. 178.
} 
problems faced by the society. This means that Teungku must be able to be moderate with differences in people's thought. Especially in Aceh, there are various thought when addressing things that are sunnah. Furthermore, differences are inevitable things. Therefore, the best way is to build a culture of tolerance. ${ }^{3}$

Tolerance in the interreligious community becomes very important in order to maintain harmony in community life. If this is not the case, the students who gained an understanding of the existence of a different group from Ahl al-Sunnah wa al-Jama'ah, are considered as the wrong person who must be avoided.

The biggest impact is making a takeover bid of mosque management from people claimed as Wahabi to Ahlul Sunnah Wal Jamaah. One of the mosques was in Krueng Mane, al-Izzah, which had been taken over from previous council that was seen as Wahabi. In fact, according from several media, the management was Muhammadiyah. However, somehow, they were called as Wahabi. ${ }^{4}$ This phenomenon is clearly not able to realize interreligious conducive atmosphere. On the contrary, there will be mutual distrust and hostility because of different understanding. This shows that Muslims in Aceh are lack of ukbuwah.

Dayah is an autonomous entity handing religious education. Dayah was founded and managed by Teungku or commonly called as Abu, Abi or Walid. Teungku automatically organizes all activities in the form of acts of worship and construction of Dayah. According to Amiruddin ${ }^{5}$, Dayah is the oldest educational institution in Aceh aiming to guide Islam generation generally through education for becoming human being with Islamic personalities. They are expected to become more beneficial in a wider community.

In Aceh, historically and culturally, Dayah has been used as a training center for a long time in which also becomes the center of Islamic development prevailing in the midst of the society. Dayah is seen as the "father" of Islamic education founded by demands and needs of the era. The existence of Dayah is one of the points in implementing Islamic teachings. From Dayah, Ulama and their Cadre are emerged determining the success of da'wah in Islam.

One of the most important components in Dayah education system is the leader. According to Syamsul Hadi Thubany in his paper Relasi Kyai-Santri, as quoted by Sri Suyanta ${ }^{6}$, Teungk $u$, in general, it is perceived as an integrative person who reflecting scientific tradition and leadership, 'alim, mastering religion (tafaqquh fi al-din), and promoting the appearance of virtuous behavior (al-karimah). It is known that someone who has higher education, wisdom and tawadhu' will get respect from his santri, and vice versa.

3Ibid., p. 177.

${ }^{4}$ http://www.tebarsuara.com/2016/05/masjid-krueng-mane-masjid-yang.html Accesed on 27 Maret

2017.

${ }^{5}$ Amiruddin, M. Hasbi., Menatap Masa Depan Dayah di Aceh, (Banda Aceh: PENA, 2008), p. 41.

'Suyanta, Sri., Idealitas Kemandirian Dayah, in Jurnal Ilmiah Islam Futura, Vol. XI, No. 2, (2012), p. 22 -

23. 
The conception of authority has defined its function to be the normative ethic of dayah which has its own peculiarities. It is indicated by traditional authority sources laid in some position such as elders (elder people), fathers, trustworthy people, respected people, official occupants, and masters of religious knowledge, and as the leader of pesantren or dayah.

This degree of charismatic authority is in the form of total respect and obedience of the people even blind taklid, therefore the judgment of a particular case no longer needs any questions, claims or critically debated. As, this was obtained from the logical consequences of religious science mastery balanced by mature character and akblaq alkarimah, Teungku is seen not only as an examples of religion science, but also as an example of behavior which is fundamental. Blessing implicate in love and obedience. ${ }^{7}$

Traditional Dayah emphasis more on teaching fiqih, taubid, kalam, mantiq, and tasamuf. Related to the problem of various ideologies, Teungku teach it towards kalam lesson. However, the picture given is only limited, and the most dominant is the study of the Asy'ariyah and Maturidiyah. The discussion which was dominated by the Ash'ariyah is related to the Dayah's understanding based on Sunni.

There is a proposition "...sesunggubnya ummat ini akan berpecah belah menjadi 73 (tujuh pulub tiga) golongan, (adapun) yang tujub pulub dua akan masuk. Neraka dan yang satu golongan akan masuk Surga, as stated in al-Jama'ah," ${ }^{8}$ hence, all forms of understandings and views that are different from those who receive education in traditional dayah will be labeled as negative deviating from the true teachings of Islam. This measure is only limited to the understanding they have. Moreover, as explained earlier, the system of transferring knowledge from teungku to santri in traditional dayah is an absolute truth that must be accepted. Whatever is taught and delivered by teungku is a truth that is not in doubt.

The learning model in traditional dayah does not provide space for differences of opinion between teachers and students. When the teacher (teungku) explains something, the student will take it for granted as in the view of the pupil (santri) whatever the teacher says is an irrefutable truth. They are seen having quite a lot of knowledge from their former and respected teacher. Therefore, it is very unlikely for santri to ask what the teacher has said. Santri believe in their teacher. Debating teacher is not a tradition developed dayah system. Moreover, presenting a number of arguments and evidence that became a comparison with the knowledge delivered by the teacher is also not their tradition. When the teacher said that the Wahhabis were heretical, the santri would accept the statement without rebuttal. When santri finishes their study and build their own dayah, they will transfer it to their santri.?

As, in dayah tradition, the santri highly respect their teacher fanatical towards the teacher, they do not dare to say that the teacher's statement is wrong. Santri will fully follow all the knowledge taught by the teacher, without any desire to open another book in

${ }^{7}$ Ibid., p. 23-24.

${ }^{8}$ HR. Abu Dawud (no.4597), Ahmad (IV / 102), al-Hakim (I / 128), ad-Darimi (II / 241). Validated and approved by Imam adz-Dzahabi dari Mu'awiyah bin Abi Sufyan. Validated by Syaikh Albani. See Silsilatul Ahaadiits ash-Shabiihah (no. 203-204).

${ }^{9}$ Interview with Teungku Faisal, Alumni Dayah Tradisional, 5 September 2017 
a different version in which the dynamics of thought will emerge referring not only to one opinion. When the teacher reads a different book, two perspectives will emerge. It is not negative, but it is possible to add information that is actually positive. Unfortunately, this tradition is not applied in Dayah in Aceh.

As mentioned above, one of the consequences of the total respect and obedience of santri to teungku is a blind taklid attitude, especially, in facing difference reality. As a result, these santri only know the truth based on only one perspective conveyed by the teungku dayah. Everything seems different from what they have received considered wrong. This leads to an anti-attitude towards differences. It is seen from how the santri respond to differences in understanding resulting riots or even leading to physical disputes. This learning model is not good seeing differences are unavoidable.

\section{What and Who is Wahabiyah: Facts and Understanding of Aceh Dayah Ulama}

Muhammad bin Abdul Wahhab thought are purification restoring Islam as taught by the Prophet Muhammad after Islam experienced dangerous deviations, especially the unity of God, such as the cult of the wali and syekh tarekat. ${ }^{10}$

The main purpose of Abdul Wahhab's teachings is to purify of people tauhid which have been contamined. For this reason, Abdul Wahhab was very serious in eradicating bid'ah, khurafat and superstition developed among people. Abdul Wahhab opposed worshipping of saints and visiting sacred places for searching blessings. Abdul Wahhab considers that all objects of worship except Allah are false. According to him, seeking help from anyone except Allah is syirik. ${ }^{11}$

Wahabi has been heralded deviant lately followed by disputes between Sunni or Ahlul Sunnah Wal Jamaah and Wahabi. The term Wahabi or Wahhabism is actually given by people outside that ideology. Wahabi calls themselves as "al-Muwabhidun" or "Ablu atTaubid". This term reflects the desire to use the principle of monotheism exclusively which is the basic foundation in Islamic teachings. ${ }^{12}$

There are several issues that continue to be a dispute between Wahhabis and Abl alSunnah wa al-Jama'ah. Following are Wahabi doctrines disputed by Sunni in the book Hamid Algar quoted by Ahmad Sidqi ${ }^{13}$. First, the tasyrik doctrine or judging a certain amaliyah as part of Syirik or refusing Allah. ${ }^{14}$ Second, concept characterizes Wahhabi doctrines called as bid'ah $^{15}$. Bid'ah according to Wahabi is religious practice which is not based on al-Qur'an

\footnotetext{
${ }^{10}$ Ibid., p. 975.

${ }^{11}$ Muhammad, Herry., et. all.., Tokoh-Tokoh Islam Yang Berpengarub Abad 20, (Jakarta: Gema Insani, 2006), p. 246.

12 Algar, Hamid., Wahabisme: Sebuah Tinjanan Kritis, (Jakarta: Yayasan Abad Demokrasi, 2011), p. 1920.

${ }^{13}$ Shidqi, Ahmad., "Respon Nahdlatul Ulama (NU) Terhadap Wahabisme dan Implikasinya Bagi Deradikalisasi pendidikan Islam", on Jurnal Pendidikan Islam, Vol. II, No. 2, (2012), Pg. 114.

${ }^{14}$ Ibid., p. 49-50.

${ }^{15}$ Bid'ah is etymologically derived from the word Bada'a means to create or create something previously there is no claim in the Quran and al-Hadiths, heretics are found in two areas, namely; First, the field of Aqidah means requiring beliefs that are not found in Islamic teachings or creating new beliefs and or changing the basis of Islam, secondly, the field of fiqh or worship is making new things in the field of worship Not in accordance with Shari'an Islam. Harahap, Syahrin., and Nasution, Hasan Bakti., Esiklopedi
} 
and Sunnab ${ }^{16}$ and Prophet's companions. Therefore, Wahabi concept of bi'dab has a negative opponent of Sunnah. ${ }^{17}$

Furthermore, bid'ah is also seen as having gripped Muslims in various other practices that are more dangerous. Among the religious practices categorized as bid'ab by the Wahhabis, namely: The commemoration of Prophet Muhammad birthday is a popular tradition among Muslims in Indonesia, especially in Aceh. The tradition which falls every 12th of the Rabiul Awal is also known as the day to commemorate the birth of Rasulallah Saw and worth the sunnah, which is to get a reward if we want to do it and not sin when left.; Tablilan, a routine carried out by the Javanese community to pray for the families of the dead. Tablilan is carried out aiming for the deceased family being forgiven of his sins while living in the world.; Grave Pilgrimage is an activity of visiting family, relatives or scholars graves who have contributed to the process of the development of Islam.; Prayer and Remembrance Congregation is an activity carried out by a Muslim as a sign and the way a servant asks or worshipes his God.; Tawassul is to get closer or plead with Allah SWT through an intermediary who has a good position with Allah.; Reciting Qunut, is a reading or prayer while carrying out morning prayers when tuma'ninah ruku 'on the second rakaat. This is only read by Nahdiyyin or NU as the other teaching considers it as Bid'ah.

\section{Dayah Teungku Concern about Wahabi}

A charismatic ulama ${ }^{18}$ in Aceh residing in the research area states that Wahabiyah is ideology that is not in line with Ablul Sunnab wal Jamaah (ASWAJA). Therefore, it should not be followed and seen as heretical. However, they cannot be called Kafir as it is not permissible to call Kafir for Muslims who still worship Allah SWT. They are called heretical as their ideology is Ablul Sunnab wal Jamaah. The indicators used in mentioning that the Wahabiyah is heretical are related to the Wahabiyah view that Allah is located in arasy. Believing Allah is located in arasy means that Allah has the place as his creature. This view is clearly misleading and cannot be followed, because it has deviated from Ahlul Sunnah wal Jama'ah's view .

Strong rejection of Wahhabi existence is also closely related to the discourse about the substance and nature of God. This discussion has become classic problems occurred since hundreds of years ago referring to Ash'ariyah opinion that God has character. As stated by al-Asy'ari that it is impossible that God knows His knowledge by His essence, as it means that His essence is the Knowledge itself. God is not knowledge but He is the

Akidah Islam, (Jakarta: Kencana, 2003), p. 76. See also Jaelani, Bisri M., Encyclopedias of Islam, (Yogyakarta: Panji Pustaka, 2007), p. 83.

${ }^{16}$ Sunnah means tradition, customs, in the term Syara' is a tradition done by the Prophet Muhammad and continued by the Salaf. See in Mudhofir, Ali., Dictionary of Theory and flow in philosophy and theology, (Yogyakarta, Gadjah Mada University Press, 1996), p. 246.

${ }^{17}$ Ibid., p. 50.

${ }^{18} \mathrm{Name}$ of the respondent disguised 
Knower. Moreover, that applies to other attributes such as living, omnipotent, all-hearing, and all-seeing. ${ }^{19}$

Accoring to Asy'ariyah, God has attributes mentioned in Qur'an such as Ilmu, Qudrat, and Hayah etc. Those are pre-eternal. Those attributes are not His essence yet inseparable from it. ${ }^{20}$ Ahlussunnah wal Jama'ah does not limit His attribute to 20 attributes. Ahlussunnah wal Jama'ah assigns those 20 attributes because they are essential attributes of God. While other Allah's attributes are shifat af'al (attributes related to His acts). These attributes are limitless.

Ulama dayah and Teungku Dayah believe in notion that if a person wants to know Allah, he has to be familiar with His attributes, also known as The 20 Attributes. If a Muslim does not know Allah's 20 Attributes, he can not know Allah as The Creator of The Universe. The main basis for understanding tauhid knows Allah the Ultimate One by learning the 20 attributes, and knowing his impossible attributes. Being ignorant to the 20 attributes is tantamount to being ignorant to Allah. If an ideology does not acknowledge the existence of the 20 attributes and only recognize His essence, so how will he know his Creator. Understanding the 20 Attributes is a starting point and a basis for a Muslim to know his God. Therefore, in a traditional dayah, learning the 20 Attributes is an obligation and a basis for developing aqidah. The wahhabiyah's view of aqidah, however, does not recognize the 20 attributes as a basis for developing an understanding of Allah. ${ }^{21}$

The matter of fiqh, particularly issues related to how we worship Allah, is a matter of importance and has to be placed under scrutiny by a Muslim of Ahlussunnah wal Jama'ah. In shalat, for instance, if an Imam does not mention the niat simultaneously with the act, that Imam can not be followed. The same thing applies if the imam does not recite Bismillabirrahmanirrabim. If one already followed that imam, after the makmum realize the mistake, that makmum has to go out of the jama'ah and perform the prayer on his own. This view was conveyed by charismatic ulama, with a lot of santri follower, at the time of interview.

Another example is if an imam does not recite the qunut in shubuh prayer, he can not be followed. A Muslim claiming to be an Ahlussunnah wal jama'ah has to observe Shafi'i school of Islamic jurisprudence. He has to observe Shafi'i school in performing worship, and obeying Islamic law. Mixing between one school and another in performing worship and Islamic law is strictly prohibited.

In line with these charismatic ulama, Teungku Sns also mention that talfiq, mixing several schools in an act of worship, is prohibited. In Maliki School's view, if a dog lick part of our body, it has to be dismembered. If so, whenever people who observe and follow Maliki's school got licked by a dog, he has to dismember parts of the body that got licked. Of course there is not being a person who would do that. If a person follows shafi'i school, he has to observe and follow everything related to the laws, and jurisprudence. This is the principle that is held by dayah ulama and their student.

${ }^{19}$ Nasution, Harun., Teologi Islam: Aliran-aliran, Sejarah, Analisa Perbandingan, Cet. V, (Jakarta: UIPress, 1986), p. 69.

20 Ahmad, Muhammad., Taubid Ilmu Kalam, (Bandung: Pustaka Setia, 1998), p. 180.

${ }^{21}$ An interview with Teungku Sanusi, Bireun, November 10th 2017 
The same thing is conveyed by Muhibbuddin al-Bayani, a teungku, a member of Majelis Permusyawaratan Ulama (MPU) and chief of MUNA Aceh Jaya. He explained thah Wahabi is one of the sect emerged in Saudi Arabia. Its founder was Muhammad Abdul Wahhabi. This sect arises at the same time with other sect such as Syi'ah, Mu'tazilah, and others. Wahabi and Syiah still grow to this day, and there is hostility between them (meaning that they fault each other).

According to Teungku Muhibbuddin al-Bayani, there are 9 specific traits of Wahabi represent the overall how Ahlussunnah wal Jama'ah perception of Wahabi as follows:

\begin{tabular}{ll}
\hline No & \multicolumn{1}{c}{ Specific Traits of Wahabi } \\
\hline $\mathbf{1}$ & $\begin{array}{l}\text { Anyone who considers Muslims, who perform tawassul to The Prophet to be } \\
\text { infidels, and permit their blood to be spilled, is a Wahabi. }\end{array}$ \\
$\mathbf{3}$ & $\begin{array}{l}\text { Anyone who believes in the view that Allah is located on the Arsy, is a Wahabi. } \\
\text { be forbidden }\end{array}$ \\
$\mathbf{4}$ & $\begin{array}{l}\text { Anyone who forbids maulid of The Prophet, and considers those who celebrate the } \\
\text { birth of the Prophet to be infidels, is a Wahabi. }\end{array}$ \\
$\mathbf{5}$ & $\begin{array}{l}\text { Those who forbid the recital of the Qur'an for the deceased, and believe that recital } \\
\text { of sura yasin on Thursday night will not benefit the deceased, is a wahabi. }\end{array}$ \\
$\mathbf{6}$ & $\begin{array}{l}\text { Wahabi is those who believe tha Allah sits or resides on the Arsy, on in the sky. } \\
\text { Wahabi also believes that saying ushalli and reciting the niat at night is not the right } \\
\text { thing to do. }\end{array}$ \\
$\mathbf{7}$ & $\begin{array}{l}\text { Anyone who interpreted istiwa 'in the Qur'an means' sitting ', and interpreting that } \\
\text { God sits on' arsy, no doubt that they are Wahhabi. }\end{array}$ \\
$\mathbf{8}$ & $\begin{array}{l}\text { Anyone who adopts God with a bodily body, such as God's feet, hands, faces, it is } \\
\text { undoubted that they are Wahhabi. }\end{array}$ \\
\hline
\end{tabular}

\section{Tracing the Existence of Wahabiyah in Relation to Muhammadiyah According to the Dayah Teungku}

The discourse with Wahabiyah which later claimed to be a heretical ideology also affects the people who were members of the Muhammadiyah organization. The relevance of Wahhabism and the practice of worship of people in Linkup Muhammadiyah is considered to have similarities, especially talking about a number of things Bid'ah which is still carried 
out heavily by Acehnese who call themselves ASWAJA, anyone who would consider the warning of the Birthday of the Prophet to be claimed as Wahabi, as well as those who did not read qunut during the Morning Prayer.

However, it is found that there are differences between Muhammadiyah and Wahabiyah, but in reality both are equated resulting Muhammadiyah citizens tend to be shunned because they are considered to have deviated from Islamic aqeedah. There are still many internal religious conflicts such as those heard in recent years. As the claim arises that it is the Muhammadiyah mosque and this is the Ahlul Sunnah wal Jama'ah mosque, or a group of Muslims. That Muhammadiyah people must pray in their own mosque, not with the other, offer prayers in mosques that are not Muhammadiyah. In Bireun, for example, it was clearly visible on the edge of the Banda Aceh Medan main road, standing majestically a mosque named the Muhammadiyah mosque. The name of the mosque was at-Taqwa, but the people there mentioned the Muhammadiyah mosque, because the pilgrims were from a large Muhammadiyah family.

A local villager said that the mosque was for Muhammadiyah residents, so no Muhammadiyah people prayed at the mosque. People who call themselves the Jamah Ahlussunnah wal Jama'ah pray in their own mosque. In the observation of the researchers, the situation in Bireun city is interesting to study, especially the problems related to socioreligious relations between Muhammadiyah and the people who call themselves Ahlussunnah wal Jama'ah as there are strict limits between them. The boundary separates a sharp difference from aqeedah and worship. How not for a mosque that is actually used as a place of worship to Allah SWT. it must be distinguished between the people who are members of the Muhammadiyah organization and they call themselves Ahlussunnah wal Jama'ah. Unlike the lives of people in Banda Aceh, as a place of residence for researchers, it is very rare to find a separation between one mosque and another mosque. Where there is a mosque, a Muslim or Muslim will perform a prayer service, without asking this, the Muhammadiyah mosque or Ahlussunnah wal Jama'ah22.

The case of the claim against the mosque does not actually occur among Muslims, because the mosque is a house of worship intended to worship Allah Almighty, regardless of which person comes from which sect. But the claim on the appointment that someone has become a member of the organization makes the breakup of friendship and brotherhood of fellow Muslims. Even the prayer place must be different, there is the Muhammadiyah mosque and there is a mosque for Ahlussunnah wal Jama'ah.

Then, is the Wahabi and Muhammadiyah the same? Teungku M said that the difference between the two understandings is that if there are khilafiyah on furu problems, for example Muhammadiyah people do not do qunut because they are considered as the hadith which is the basis for qunut included in the dhaif hadith, which cannot be used as a source of law to do qunut. Whereas Wahabi, their incompatibility with Ahlussunnah wal

${ }^{22}$ An interview with Fitri, a local of GT,Bireun, Aceh 
Jama'ah is on the issue of i'tiqadiyah, even though they cannot be classified as infidels, but have begun to lead to the infidel group.23

The offense of the Muhammadiyah organization in Wahabiyah matters was based on the assumption that Wahhabi had infiltrated Muhammadiyah's body. Even the dayah teungku ensured that 90 percent of Muhammadiyah people had Wahhabism. The argument of the dayah teungku is based on the practice of worshiping the Muhamadiyah people who allegedly have similarities with Wahabiyah. Rejection of the nature of 20 was the main reason for the emergence of differences in Ahlussunnah wal Jama'ah with Wahabiyah. The procedure for worship which is seen as different from Ahlussunnah wal Jama'ah is also another reason to equate Wahabiyah with Ahlussunnah wal Jama'ah.

The refusal of Muhammadiyah for some rituals of Islamic teachings even mentions it as a doctrine that has no basic and not exemplified by the Prophet, as bid'ah, adding a long list of records for those who call themselves Ahlussunnah wal Jama'ah, against his unequal brother Wahabiyah. For Aceh especially research areas such as Bireun, North Aceh, that people who did not follow the Maulid celebrations in the form of large feasts, and did not perform tahlilan for the deceased, then quickly, people would claim that the person is Wahabiyah or Muhammadiyah.

The main problem of the heretical setting for Wahhabi is still the assumption that Wahhabism argues that Allah is located in 'arsy. This view is understood as a form of error and a fundamental difference in the view of monotheism between those who call themselves Ahlussunnah wal Jama'ah and those who are considered Wahhabis. The difference in 'itiqad has caused Wahabi people or anyone who has Wahhabi heresy. Not only in the issue of i'tiqad, but problems related to the ordinances of worship have also become the main problem that distinguishes between Ahlussunnah wal Jama'ah and Wahabiyah. Just mention the qunut problem, the intention to accompany prayer for a Muslim. This becomes a long polemic that cannot be parsed and leads to the problem of who is misguided and not misguided.

Not only related to the question of faith and worship, but the question of Wahabiyah courage or later associated with the claim of bid'ah to Ahlussunnah wal Jama'ah in the course of performing some religious activities such as the feast of mawlid, feast when someone dies, seven days in a row without pause, pay fidhiyah prayer. This claim of bid'ah has provoked the people who call themselves Ahlussunnah wal Jama'ah to also reply Wahabiyah's words by calling them astray, especially their views which say that Allah swt is in 'arsy.

Teungku Zulkifli, one of the leaders of one of Birah's diaries, mentioned that the differences related to the fiqh were not a problem, there was still tolerance if only the qunut and intentions accompany the prayers. It's a difference in furu 'that does not need to be spelled out. Difference is a blessing that must be understood in the form of maturity of

${ }^{23}$ An interview with Teungku M. 
thinking. But the fundamental problem is the difference of aqidah, and when the difference concerns aqidah, then there is no tolerance, the punishment of waliyadin. The wrong understanding of aqidah will impede a person from the Muslims to be infidels. In the hadith of the Prophet Muhammad. it has been mentioned that Muslims will be split into 73 groups, and there is only one survivor. Those divided are Jabariah, Qadariah, Shi'ite, Wahhabi and other tribes. For Wahabiyah's fundamental setting of their deviation is when they dare to interpret the verses mutasyabihat. Though these verses can not be interpreted because only Allah swt. who knows the meaning. While in the dayah it holds the faith of Ahlussunnah wal Jama'ah, which does not allow the interpretation of mutasy verses. Wahabi understanders also denounce takwil, denial of takwil as well as denying the Qur'an.

Furthermore Teungku Zulkifli said that this difference in i'tiqad (aqeedah) affected the deviation from the Ahlussunnah wal Jamaah aqeedah. Belief in Allah SWT. or monotheism and a Muslim are very important and cannot be negotiable. If there is someone who has said that Allah SW'T. located in 'arsy, it has been deviated. Moreover, menyifati Allah is the same as being. This action cannot be tolerated for any reason. Aqeedah is the main basis for Muslims, so that other acts of worship are upheld.

Related to the relationship between Wahabiyah and Muhammadiyah, Teungku Zulkifli mentioned that Wahabi had infiltrated the organization of Muhammadiyah, meaning there are many Wahhabi people in Muhammadiyah organization. Indications for such claims are based on the practice of worship and understanding of the tauhid of the Muhammadiyah people, which are considered to be the same as Wahabiyah. However, teungku Zulkifli did not mention the heathen to the Wahhabi, only mentioned they had gone astray.

This heretical mention clearly impacts on the social relations of the community, resulting in a clear distance between one community and another, with Muhammadiyah's identity or not. Referring to this problem, the researcher asked Teungku Zulkifli, how should the attitude of the community address this issue. Teungku Zulkifli said that he had to take distance, or distance himself from people who have Wahhabism. This attitude was taken so that the people were not affected by Wahabiism, because if they were unable to argue, then the person would follow Wahhabism.

Regarding the view of the community's attitude towards Wahabi people, the community must maintain a distance, not to be influenced by this understanding. When this statement reaches the community, what happens is the attitude of the community's antipathy towards all matters related to Wahabiism, one of which is the claim directed at Muhammadiyah organizations and the people who are members of the organization. The community directly appoints Wahabi for anyone who does not read qunut, who is not feuded with maulid, does not take care. Every time there are acts of worship or thoughts that are different from the community, it will be claimed to be Wahabi.

It is interesting to explore further in the villages around Teungku Sanusi's residence, there was a very strong attraction between Muhammadiyah residents and the people who 
called themselves Ahlussunnah wal Jama'ah. For example, a mosque that was once managed by a community from the Muhammadiyah organization was taken over by a community that called itself Ahlussunnah wal Jama'ah. The surrounding community did not want the mosque to be managed by residents who were members of the Muhammadiyah organization, then they tried not to elect the village head from Muhammadiyah people. Previously the village was led by the village head from the Muhammadiyah organization. When the village head of the Muhammadiyah people, the mosque had priests and administrators who were all from Muhammadiyah. The surrounding community did not accept the condition well, but could not do anything, because the village leadership of the Muhammadiyah people.

Then when the village head's period ended, the community tried to find support for new village heads who were not Muhammadiyah people. When new village heads are elected, and not Muhammadiyah, the surrounding community makes the mosque a community mosque of Ahlul Sunnah Wal Jamaah, and no longer a Muhammadiyah mosque. Residents prayed at the mosque, and Muhammadiyah residents then looked for other land to establish mosques. The establishment of the new mosque was also a polemic, until it had to be resolved by the district and provincial religious ministries.

Ummi Fitriani said that residents now want to carry out congregational prayers in their villages, even tarawih prayers have been carried out with reference to the teachings of Ahlussunnah wal Jama'ah, carried out twenty rak'ahs, and several other procedures according to the guidance of teungku dayah. Previously the mosque had performed tarawih eight rak'ah prayers. The community also feels happy, because in this village there is already one traditional Islamic boarding school who practices Islamic teachings in accordance with the Ahlussunnah wal Jama'ah faith 24

Ummi Fitriani as a dayah alumni and had completed her study in dayah for almost seven years, also mentioned that in the body of the Muhammadiyah organization it was mixed with Wahabi. Harder Ummi Ftriani mentioned that Wahabi is a teaching spread by Jews, and has gone astray, so it cannot be followed. Ummi Fitri also mentioned that he had read a book which stated that Wahabi was a heretic. As for the delivery of the others, the Wahabi heresy still revolves around their understanding of Allah SWT which is located in 'arsy.

The understanding that Wahhabi has deviated from Ahlussunnah wal Jama'ah aqeedah has become the guideline of all the teungku dayah, especially from some of the families who were interviewed. For example, Teungku Sanusi said that Wahabi intellectuals had dared to change the books of Ahlussunnah wal Jama'ah with Wahabiism. Even in the great books of Imam al-Ghazali there has also been a change that was infiltrated by Wahabi followers, so it needs caution for the santri to read the books that are now. For example, reciting in a grave and festivity in a deceased person is already called bid'ah, even though the act has a strong foundation, as studied by teungku dayah.

\footnotetext{
${ }^{24}$ An interview with Ummi Fitriani, Dayah Tradisional Alumni.
} 
There is a kind of transfer of understanding given by the teacher reciting the santri, both santri from among women, male or female students. Initially when there was no transfer of understanding to Wahabiyah and Muhammadiyah, it was clear that there was no fear from someone to get along and live with his brothers from the Muhammadiyah organization. But after there was a transfer of understanding that the heretical Wahabiyah had to be shunned, by being obedient without any clarification and in-depth study of the understanding, many people then gave antipathy towards Muhammadiyah people.

A teungku Dayah named Sy, in a private study to the house of Ibu Fitri, said that Muhammadiyah people who had Wahhabi beliefs differed from aqeedah with Ahlussunnah wal Jama'ah, therefore they were forbidden to marry Wahabiyah people (if in Bireun people were referred to is Muhammadiyah). Marriage must be done with people who have the same intention. Muhammadiyah has different i'tikad with Ahlussunnah wal Jama'ah. The intention is the opinion that says Allah. located in 'arsy. This is the most basic problem of the teungku saying that Muhammadiyah has been different from 'tikad with Ahlussunnah wal Jama'ah.

As a result of the very harsh claims against Wahhabi people, who are considered part of Muhammadiyah, some couples have to hide from their families, that they have married Muhammadiyah people. It cannot be imagined if his parents knew that his son's partner was Muhammadiyah. But one thing that should be commended is the attitude of this couple who can accept all traditions in the family. Following all religious activities carried out by family-in-law, without asking any questions, so that there was no impression of the slightest difference between himself and his family-in-law.

In the tradition in Aceh there is something called peusijuk (ditepungtawari) with the aim that all new activities can run smoothly. Likewise during marriage, there is a process intended by the family. This activity is also well followed, without disputes, with the aim of maintaining family-in-law's feelings so that misunderstandings do not arise and can lead to unwanted things.

So complex are the problems that arise due to the transfer of knowledge given by a teungku to his students. Moreover, if a student (santri) is very fanatical about his teacher, and follows everything that is conveyed by the teacher without questioning or reviewing objectively what the teacher said. This will lead to a misunderstanding in the community and in the end can break the ties between brothers and sisters in Islam.

\section{The Effect of Wahabi Stigma on the Emergence of Social Conflict}

Although this statement is still considered premature, some cases of mosque controlled and claimed as Muhammadiyah or Ahlussunnah wal Jama'ah mosques have disturbed the interreligious relations. If claims towards Wahhabism are only seen and measured by differences in mazhab or Fiqih, Wahabi refers to all people who are different in terms of implementing Islamic especially relating to worship. When people come into contact with their wives or not join maulid feast called as Wahabi a fanatical society without a proper 
knowledge will immediately take anarchic actions to hamper the development of Wahabi fearing it affect the younger ASWAJA generation.

The above cases are social social phenomena which potentially broke unity if a solution is not taken to mediate the problem. Providing a comprehensive explanation about the difference between Muhammadiyah and Wahabiyah is one of solution for avoiding any claim from the community that the Muhammadiyah is Wahabi.

In Aceh, if there any belief is called heretical, it will be easy to provoke it as they are fanatic. However, when an intolerant attituate appear, it becomes a serious problem if it is not handled properly.

When Wahabi arises in a society, rejection comes after. Especially, if there is an attempt to build a mosque in a community, people who have no sympathy will come together to reject it. They afraid there is no recitation of salawat, tarawih in 20 rakaat, qunut, and etc.

As stated by Ummi Fitriani, that when a traditional Islamic boarding school is established in a village that used to be a lot of people who are members of the Muhammadiyah organization, the people there are very happy and try to build the dayah by providing various assistance. Furthermore, when there are no mosques in the pesantren, the community carries out tarawih 20 rakaat prayers at the very small dayah hall, so that large numbers of people can not be accommodated above the small hall. Whereas there is a mosque around the village, but the community does not want to pray there as it is not carried out according to the understanding of teungku dayah.25

This shows that the community strongly believes only worship as taught and practiced by the Dayah teungku, and in accordance with ASWAJA while the rest is deemed deviant. This is clearly different in Banda Aceh where mosques hold tarawih prayers in two versions, which are 20 rakaat and 8 rakaat. The community just has to choose which one to follow. Nobody claims right and wrong. However, this was not seen in Bireun as there is a division of understanding that those who prayed 8 rakaat called as Muhammadiyah and those who prayed 20 called as ASWAJA.

One of the impacts arose due to intolerance in the community was the takeover of mosque management from the person claimed to be Wahabi to the more entitled ones, namely ASWAJA. One of the mosques in Krueng Mane, al-Izzah, has been taken over from who were previously considered Wahabi groups. In fact, according to sources from several media, the mosque is a mosque whose management is people from Muhammadiyah organizations. But somehow, they suddenly shouted at Wahabi.26

\footnotetext{
${ }^{25} \mathrm{An}$ interview with Ummi Fitriani.

${ }^{26}$ http://www.tebarsuara.com/2016/05/masjid-krueng-mane-masjid-yang.html accessed on March
} 27th, 2017. 
Another incident that shows the immaturity of the community in dealing with differences is the takeover of the Great Mosque of Bireuen. The mosque is also known to the elders by the name of 'boh u' (coconut fruit) because many people donated coconuts for the construction of the mosque. Since the beginning of its construction, this mosque has implemented the worship method as understood by 'Muhammadiyah'. And the majority of the administrators at that time were 'Muhammadiyah'. Since the imum syik is Ust. Daud Hamzah and so on, until a local government coup d'état occurred in 2007, at which time the Regent revoked unilaterally the decree of the mosque administrator, arguing that it had become a district mosque (there was an appendix of the 'Agung '(Great Mosque)). And it happened politically because it was ahead of the elections. Fearing bloodshed, the mosque administrator at that time called on Jama'ah not to fight. Finally, the success of the mosque management was carried out, and the procedure for implementing the worship was changed according to the understanding of 'NU / Pesantren / Dayah'.

The most recent case is the incident where the Samalanga mosque was burned by residents. The foundation and veranda of the mosque which was newly built by the Muhammadiyah congregation in Aceh was burned by a group of unknown people. The burning was allegedly because the existence of the mosque was deemed to be incompatible with the teachings of Ahlussunnah wal Jama'ah (Aswaja) practiced by Islamic boarding schools in Aceh.

The incident was confirmed by Muhammadiyah Youth Chairperson Dahnil Anzar Simanjuntak. Dahnil said, the construction of the Taqwa Muhammadiyah Mosque in Samalanga, Bireun District was basically equipped with building permits. "Indeed, lately, especially Bireun, there are often objections that reject the establishment of the Muhammadiyah Mosque because it is considered to be incompatible with Aswaja or traditional teachings practiced by dayah-dayah (pesantren) there," said Dahnil.

This phenomenon is clearly not able to create a conducive atmosphere between religious brothers. On the contrary there will be mutual suspicion, and mutual hostility, only because of understanding different religions. This shows that Acehnese Muslims are experiencing an emergency condition of ukhuwah. Such conditions are a fact that happened to the Veranda of Mecca land, and the area that was very vulnerable to violence in the name of religion was Bireuen District. Friction, tension, violence, and conflict triggered by religious groups are a common sight. Islam that is universal, inclusive, tolerant, democratic and upholds the values of justice has been understood by religious groups to be local, narrow, rigid and hard. Islam as a religion full of mercy has not provided its empowerment in a more real realm.

In addition to the mosque issue, the social life of the people who are members of the Muhammadiyah organization with those who call themselves ASWAJA are also no longer harmonious. In a village in the Bireun district, where there is a Muhammadiyah community divided by non-Muhammadiyah citizens. For the people who have participated 
in the recitation and get lessons from their teachers (teungku) about Wahabi who infiltrated the Muhammadiyah organization, maintaining distance in daily relations with Muhammadiyah citizens.

A woman of one of the villages in her house adjacent to Muhammadiyah residents had heard complaints from a Muhammadiyah mother, who was sad and disappointed. When her husband passed away, residents who knew that her husband was Muhammadiyah chose to go home and did not want to take part in the prayer. The grieving mother was very sadand said this is not a matter of Muhammadiyah or not, but this is a matter of fardhu kifayah which must be carried out by all Muslims regardless of status.27

This is the reality happened in the society, even though the case is only one or two, but this mindset can create social problems, especially the breakdown of friendship and even brotherhood among Muslims. If everyone thinks that Muhammadiyah is the same as wahabiyah, and this understanding has deviated from Ahlussunnah wal Jama'ah, then the majority of lay people will follow this view without clear guidance. So in the end feared will have an impact on the inconvenience of social relations among people.

Fear of differences in religion affects relation as people who are considered different ideologies will be shunned in socio-religious life. This is also an urgent homework how this unreasonable fear make people uncomfortable with associating with $\mathrm{A}$ or $\mathrm{B}$. The social life in a village will be fragmented, even though there are very few people. Coupled with suggestions, do not associate with A, because Muhammadiyah people, later A will influence other people to enter Muhammadiyah.

Of course this is not very good for the social life of the Islamic community which should lead a life full of ukhuwah and love between fellow Muslim brothers. Therefore, the thoughts and attitudes that distance a Muslim from other Muslims, only because of differences in understanding of Islamic law, do not have to be preserved. Especially in the education system, it should give enlightenment about true Islam. It is not Islam in my opinion that is correct, and all other views outside of his view are false and misguided.

\section{CONCLUSION}

The model of transferring knowledge or teaching in Dayah emphasizes tengku (ustad) as someone who conveys an irrefutable truth. In political terms, it is known as top down. Santri believes whatever is conveyed by the teacher as an irrefutable truth. This tradition continues. A santri who is become a teacher also behaves as same as his teacher. The book read by the teacher, is even read by santri. There are no different references or comparasion with other knowledge, other than from the teacher.

\footnotetext{
${ }^{27}$ An interview with Fitri
} 
The attitude is above influence santri on fostering a fanatical attitude and guessing that they are the most correct one. The truth claim arises in santri, which at the end only justifies his thoughts and considers others all wrong. The climax is the emergence of internal conflict in religion. A very obvious case happened in the research area where the local community gained an understanding from some teungku that Wahabi had similarities with Muhammadiyah which this was where the attitude of intolerance began to develop.

\section{REFERENCES}

Abu Bakar Atjeh, Salaf, (Jakarta: Permata, 1970).

Ahmad Hanafi, Pangantar Theology Islam, (Jakarta: Mutiara Sumber Widya Jakarta, 1995).

Ahmad Shidqi, "Respon Nahdlatul Ulama (NU) Terhadap Wahabisme dan Implikasinya Bagi Deradikalisasi pendidikan Islam", dalam Jumal Pendidikan Islam, Vol. II, No. 2, (2012).

Ahmad Syafi'i Maarif, Islam dalam Bingkai Keindonesiaan dan Kemanusiaan: Sebuah Refleksi Sejarah, (Bandung: Mizan, 2009).

Ali Mudhofir, Kamus Teori dan Aliran dalam Filsafat dan Teologi, (Yogyakarta, Gadjah Mada University Press, 1996).

Bisri M. Jaelani, Ensiklopedi Islam (Yogyakarta: Panji Pustaka, 2007).

Hamid Algar, Wababisme: Sebuah Tinjauan Kritis, (Jakarta: Yayasan Abad Demokrasi, 2011).

Harun Nasution, Ensiklopedi Islam Indonesia IAIN Syarif Hidatullah, Jakarta: Djambatan, 1992).

Harun Nasution, Islam Rasional: Gerakan dan Pemikiran, (Bandung: Miæan, 1995).

Harun Nasution, Teologi Islam: Aliran-aliran, Sejarah, Analisa Perbandingan, Cet. V, Jakarta: UI-Press, 1986).

Herry Muhammad, dkk., Tokoh-Tokoh Islam Yang Berpengaruh Abad 20, (Jakarta: Gema Insani, 2006).

M. Hasbi Amiruddin, Menatap Masa Depan Dayah di Aceh, (Banda Aceh: PENA, 2008).

M. Imdadun Rahmat, Arus Balik Islam Radikal (Transmisi Revivalisme Islam Timur Tengab ke Indonesia), (Jakarta: Erlangga, 2002).

M. Sufyan Raji Abdullah, Mengenal Aliran-Aliran dalam Islam dan Ciri-Ciri Ajaranya, (Jakarta: Pustaka Al-Riyadh, 2006).

Maryam Jamilah, Para Mujabid Agung, Terj. Hamid Lutfi A.B, Cet. II, (Bandung, Mizan 1976). 
Millatī, Journal of Islamic Studies and Humanities, Vol. 4, No. 1, Juni 2019: 35-52

Muhammad Ahmad, Taubid Ilmu Kalam, (Bandung: Pustaka Setia, 1998).

Mustofa Muhammad Asy-Ayak'ah, Islam Tidak Bermazhab, Terj. A.M. Basalamah, (Jakarta: Gema Insani Press, 1994).

Nur Khalik Ridwan dan M. Nur Hasyim, Demoralisasi Khittah NU dan Pembaruan, (Yogyakarta: Pustaka Pesantren, 2004).

Nurcholis Madjid, Tradisi Islam: Peran dan Fungsinya dalam Pembangunan di Indonesia, Cet. II, (Jakarta: Paramadina, 2008).

Sri Suyanta, "Idealitas Kemandirian Dayah", dalam Jurnal Ilmiah Islam Futura, Vol. XI, No. 2, (2012).

Stoddard, Lothrop, Dunia Baru Islam, Terjemahan oleh Panitia Penerbit, (Jakarta: t.p, 1966).

Syahrin Harahap dan Hasan Bakti Nasution, Esiklopedi Akidah Islam (Jakarta: Kencana, 2003).

Syekhul Islam Muhammad bin Abdul Wahhab, Kitab Taubid, Terj. Yusuf Harun, (Jakarta: Yayasan Al-Sofwa, 2007).

Tim Penulis, Ensiklopedi Islam, (Jakarta: Ichtiar Baru Van Hoeve, 2005). 